\title{
Ulcerative disease outbreak in crayfish Orconectes propinquus linked to Saprolegnia australis in Big Muskellunge Lake, Wisconsin
}

\author{
Lisa Krugner-Higby ${ }^{1, *}$, Danielle Haak ${ }^{2}$, Pieter T. J. Johnson ${ }^{3}$, Jeffery D. Shields ${ }^{4}$, \\ William M. Jones III $^{4}$, Kimberly S. Reece ${ }^{4}$, Tim Meinke ${ }^{2}$, Annette Gendron ${ }^{1}$, \\ James A. Rusak ${ }^{2,5}$ \\ ${ }^{1}$ Research Animal Resources Center, University of Wisconsin-Madison, Madison, Wisconsin 53726, USA \\ ${ }^{2}$ Center for Limnology, University of Wisconsin-Madison, Madison, Wisconsin 53706, USA \\ ${ }^{3}$ Department of Ecology and Evolutionary Biology, University of Colorado, Boulder, Colorado 80309, USA \\ ${ }^{4}$ The Virginia Institute of Marine Science, The College of William \& Mary, Gloucester Point, Virginia 23062, USA \\ ${ }^{5}$ Present address: Dorset Environmental Science Centre, Ontario Ministry of the Environment, Dorset, Ontario P0A 1E0, Canada
}

\begin{abstract}
Crayfish populations in the area of the North Temperate Lakes Long Term Ecological Research (LTER) project, Wisconsin, USA, have been monitored for $>25$ yr. In 2005, native crayfish Orconectes propinquus from Big Muskellunge Lake were found with ulcerated lesions in the cuticle. In 2006, lesions occurred in $9.5 \%$ of sampled crayfish from the lake $(\mathrm{n}=3146)$. Ulcers generally occurred on the appendages of affected individuals but varied in location and severity. The prevalence of ulcers varied widely among sites, sample depths, and sampling dates, ranging from $<2 \%$ to $>20 \%$. The prevalence of ulcers in crayfish increased from a minimum in early June to a maximum in late July and August. In aquarium trials, healthy crayfish representing either $O$. propinquus or $O$. rusticus co-housed with ulcerated crayfish did not develop ulcers within 4 wk of exposure. Gross and histopathologic analyses of ulcerated crayfish revealed the presence of filamentous hyphae in the lesions while hemocytic infiltrates, melanotic reactions and silver-stained sections indicated that the ulcers had an oomycete etiology. Excised samples of ulcerated crayfish cuticle grown in culture developed an oomycete that was identified as Saprolegnia australis by PCR amplification and sequence analysis of 2 different DNA fragments. This is the first report of the occurrence of ulcers in wild crayfish associated with $S$. australis infection in the USA. The advent of the outbreak and its underlying ecological causes are still under investigation.
\end{abstract}

KEY WORDS: Shell disease $\cdot$ Epidemiology $\cdot$ Mortality $\cdot$ Aphanomyces $\cdot$ Saprolegnia $\cdot$ Crayfish

\section{INTRODUCTION}

Oomycetes are protists with complex life cycles that are important plant and animal pathogens. Oomycetes were classified as Fungi, but genetic sequencing indicates that these organisms are more closely related to diatoms and chromophyte algae (Baldauf 2003). The common names for oomycetes, including water molds and downy mildews, reflect their archaic classification as Fungi. Oomycetes of the genera Aphanomyces and
Saprolegnia are important pathogens of cold-blooded vertebrates, including fish and amphibians, and invertebrates such as crayfish (Torto-Alalibo et al. 2005). Indeed, crayfish plague is caused by $A$. astaci, which has significantly damaged European stocks of native crayfish since its identification in 1860 (Edgerton et al. 2004).

Parasitic Oomycetes such as Saprolegnia spp. have a typical saprolegnid life cycle. Sporangia with asexual 
spores form on the tips of hyphal stalks and produce primary zoospores. Motile primary zoospores swim for brief periods before encysting as a primary cyst. Encysted primary zoospores produce secondary zoospores that are also motile infective forms, and which find a host and germinate into new hyphae. The process of producing and releasing more than one type of zoospore or infective element is called polyplanetism. Transmission of Saprolegnia spp. is a complex process involving 2 types of motile zoospore but with no intermediate host (Torto-Alalibo et al. 2005).

Oomycetes of the genus Saprolegnia, especially $S$. parasitica, are economically important pathogens of fish and fish eggs. Infection with these organisms has caused heavy losses in salmonid fish hatcheries and 'winter kill' in catfish in aquaculture settings (TortoAlalibo et al. 2005). Outbreaks of saprolegniasis have also been reported in wild salmonid fish (Carballo et al. 1995) and in the eggs and larvae of amphibians (Blaustein \& Wake 1995, Kiesecker \& Blaustein 1995, Kiesecker et al. 2001). Increased severity and prevalence of infection in fish are associated with poor water quality and damage to the integumental barrier of the epidermis (Carballo et al. 1995). In adult fish, the lesions present as large penetrating ulcers with necrotic borders, sometimes with an overgrowth of hyphae (Torto-Alalibo et al. 2005). In amphibians, Saprolegnia spp. often attack eggs laid in shallow water and cause elevated pathology in tadpoles in the presence of higher UV-B radiation (Kiesecker \& Blaustein 1995). In some amphibians, the resulting mortality can influence population dynamics and long-term persistence (Kiesecker et al. 2001). Death in fish results from a breakdown in osmoregulation resulting in osmotic shock (Torto-Alalibo et al. 2005).

Saprolegnia parasitica infections also have been reported in crayfish, both in aquaculture settings and in wild crayfish. Infections in crayfish present as 'burn marks' in the carapace then progress into penetrating ulcers. The risk factors for saprolegniasis in crayfish are likely the same as those recognized in fish, including wounding, stress from water treatments, and poor water quality. Other Saprolegnia spp. have been reported in crayfish by culturing the organisms from dead crayfish, but pathogenicity was not determined (Edgerton et al. 2002). S. australis is closely related to $S$. parasitica. Disease involving $S$. australis and related organisms has been described in crayfish from Lake Constance in Europe, but the agent has not been reported as a naturally occurring pathogen in North American crayfish (Hirsch et al. 2008).

We report on an epizootic of Saprolegnia australis in a native crayfish population from Big Muskellunge Lake, which is part of the North Temperate Lakes Long Term Ecological Research (LTER; http://lter.limnology.wisc.edu/) program in Wisconsin, USA. The first crayfish with ulcerated lesions were identified during sampling for the LTER project in 2005. During the 2006 field season, we sought to identify the organism causing the ulcers, characterize the lesions pathologically, and determine the spatial pattern of the epizootic among regions and depths within the lake. This outbreak was important because it occurred in a population of crayfish that has been continuously monitored for $>25 \mathrm{yr}$ as part of the LTER project. Ulcerated crayfish had not been observed in this system prior to 2005 .

\section{MATERIALS AND METHODS}

Study area. Big Muskellunge Lake (Fig. 1) is a seepage lake located in Vilas County, Wisconsin (Wisconsin Department of Natural Resources, www.dnr.wi.gov/ lakes/). The lake is one of 7 Northern Highland lakes included in the LTER project. Big Muskellunge Lake is a relatively undeveloped lake that is used primarily for recreational angling and boating. The lake has a mean depth of $7.5 \mathrm{~m}$ and a broad littoral zone composed largely of sand and cobble that typically supports large numbers of Orconectes propinquus crayfish (J. A. Rusak unpubl. data). The LTER program has surveyed crayfish numbers annually since 1982 (http://lter. limnology.wisc.edu/protocols.html). Briefly, crayfish have been monitored on this lake by trapping 6 sites per year, with 3 traps per site, in early August. Trapping has been conducted at a single depth $(\sim 1 \mathrm{~m})$ to date, with mean annual catch varying from a low of 0 to a high of nearly 30 individuals per trap in overnight sets over the period 1982 to 2008.

Field sampling. To characterize the spatial variation in the prevalence of ulcerative disease among crayfish, we sampled each of 4 sites in Big Muskellunge Lake 4

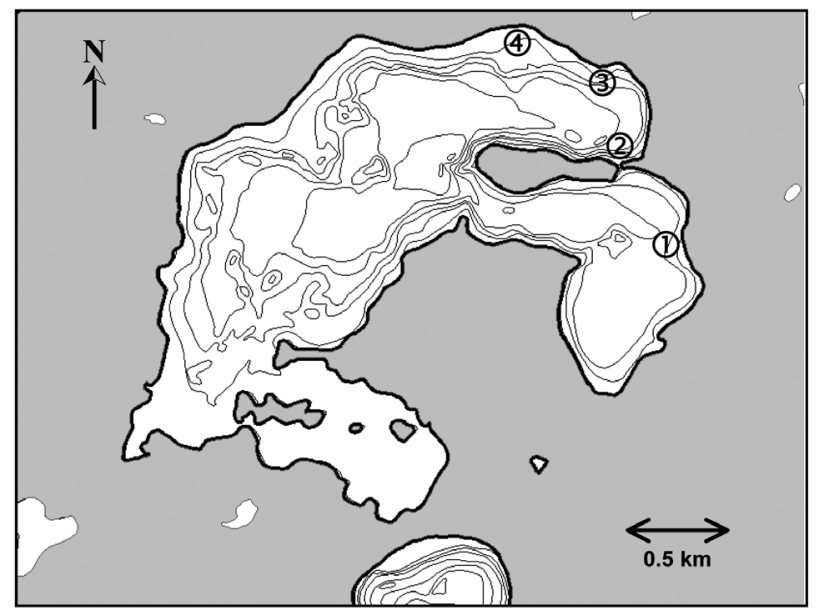

Fig. 1. Big Muskellunge Lake bathymetry (10 ft [ 3.05 m] contours) with the 4 intensive sampling sites noted. Location of the lake is $46.02^{\circ} \mathrm{N}, 89.61^{\circ} \mathrm{W}$ 
times between June and August 2006 (Fig. 1). At each site, 7 baited minnow traps were set in a transect perpendicular from shore at $1 \mathrm{~m}$ depth intervals, ranging from 0.5 to $6.5 \mathrm{~m}$. The traps were metal minnow traps in which the holes were enlarged $(\sim 5 \mathrm{~cm})$ to allow crayfish entry. All traps were baited with $\sim 0.6 \mathrm{~kg}$ of beef liver and left for 24 to $48 \mathrm{~h}$. Trap size and baiting methods were identical to the standard LTER crayfish sampling protocol (http://lter.limnology.wisc.edu/fish_ protocol07.shtml). Trapped crayfish were identified for sex and species, and examined visually for the presence of ulcers or other lesions. A randomly selected subsample from each trap (typically 5 individuals) was also measured for body length. The site and depth at which crayfish were trapped was also recorded. Sites were surveyed for ecological characteristics (Table 1).

Laboratory transmission study. A subset of crayfish from the third sampling event, including 9 infected and 9 uninfected Orconectes propinquus, were retained in aquaria to study the potential for waterborne transmission of the disease agent. Infection status was determined by the presence or absence of external ulcers or lesions. Four outdoor aquaria (42.4 l) were filled with 151 of unfiltered lake water at the Trout Lake Field Station and monitored daily for $4 \mathrm{wk}$. Each day, crayfish were examined for the occurrence of ulcerative disease, morbidity, and mortality. Water in aquaria was replaced every 4 to $5 \mathrm{~d}$.

The experiments examined the possibility of transmission within and between species of crayfish. The experimental groups were as follows: control treatments contained 3 uninfected Orconectes propinquus crayfish alone ( $\mathrm{n}=2$ aquaria); intraspecific exposure treatments contained 3 infected $O$. propinquus and 3 uninfected $O$. propinquus ( $\mathrm{n}=1$ aquarium); interspe- cific exposure treatments contained 3 infected $O$. propinquus and 3 uninfected $O$. rusticus found in Lake Laura ( $\mathrm{n}=1$ aquarium). Molt status of the crayfish was not recorded. The present study was not designed as a rigorous, replicated experiment, but rather as a preliminary exploration of whether the ulcerous condition was directly contagious.

Pathology. A total of 155 lesions were examined from a sample of ulcerated crayfish and the anatomic location of the lesions was recorded (see Table 2). Gross necropsies were performed on $>50$ crayfish over the course of 2 yr. Tissues from 10 crayfish were collected and placed in $10 \%$ neutral buffered formalin at University of Wisconsin-Madison (UW-Madison) and processed with EDTA decalcification, sectioned at $5 \mu \mathrm{m}$ and stained with hematoxylin and eosin (H\&E) and Gomori methenamine silver (GMS) stains. Gross observations and photographs were made of additional crayfish with ulcerative lesions (Fig. 2). Additional infected crayfish were placed in a cooler and shipped live to The Virginia Institute of Marine Science (VIMS) using overnight freight. A total of 13 animals were dissected upon arrival, with tissues fixed in Bouin's solution for $24 \mathrm{~h}$, washed in tap water, and stored in $70 \%$ ethanol. Several ulcerated pieces of crayfish carapace were decalcified in EDTA-sodium citrate (Luna 1968) prior to histologic preparation. Fixed tissues were embedded in paraffin, and stained with H\&E and GMS for histologic examination. Histologic sections were reviewed at both UW-Madison and VIMS, and histopathologic assessments were done independently at each institution. Carapace sections were also frozen for molecular identification of the pathogenic organism.

Bacterial and fungal culture and PCR. Swabs were taken for isolation of aerobic bacteria from the ulcer-

Table 1. Ecological characteristics of the sampling sites during the 2006 field season

\begin{tabular}{|c|c|c|}
\hline Site & Location & Habitat description \\
\hline 1 & NE bay of the lake & $\begin{array}{l}\text { Cobble and sand, with little to no macrophytes. Coarse woody habitat } \\
\text { along the shore; depth increased quickly away from shore. Shoreline } \\
\text { strip of sand and pebbles } 1.5 \mathrm{~m} \text { wide before becoming heavily forested. } \\
\text { No development }\end{array}$ \\
\hline 2 & $\begin{array}{l}\text { NE tip of Deer Island on the same half } \\
\text { of the lake as Site } 1\end{array}$ & $\begin{array}{l}\text { Cobble and sand, macrophytes present, less coarse woody habitat. } \\
\text { Located at the end of a beach connected to a group camp site. Greater } \\
\text { human use. Some shoreline cleared for more beach and open space. } \\
\text { Forest behind this open space }\end{array}$ \\
\hline 3 & $\begin{array}{l}\text { Next to a public boat landing in a } \\
\text { marshy area }\end{array}$ & $\begin{array}{l}\text { Sandy, abundant macrophytes. Water no more than } 1 \mathrm{~m} \text { deep out to } \\
10 \mathrm{~m} \text { offshore, followed by a steep drop-off. Along this drop-off were } \\
\text { fallen trees and woody debris. Marsh-like riparian vegetation and white } \\
\text { birch trees on shore }\end{array}$ \\
\hline 4 & $\begin{array}{l}\text { Further west in the same basin as } \\
\text { Sites } 2 \text { and } 3\end{array}$ & $\begin{array}{l}\text { Sandy, macrophytes present. A few downed trees in the littoral zone } \\
\text { and small amounts of woody debris. The bottom of the lake was shallow } \\
\text { for } 8 \mathrm{~m} \text { offshore, dropped off quickly, and then declined more slowly. } \\
\text { Riparian zone was marshy, soon becoming heavily wooded }\end{array}$ \\
\hline
\end{tabular}




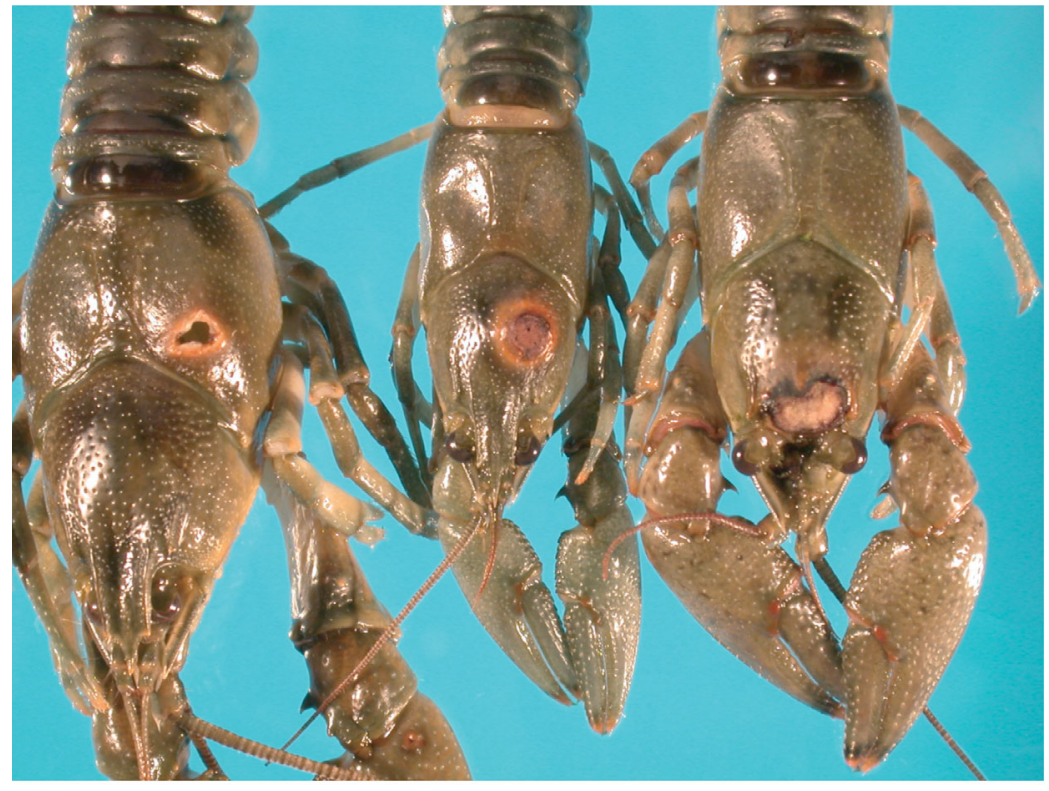

Fig. 2. Orconectes propinquus. Gross lesions of saprolegniasis. Ulcerative lesions on the carapace and legs of some of the more severely affected crayfish

ous lesions on the carapace of infected hosts. Carapace lesion or swabs from the lesions of 3 crayfish were plated on tryptic soy agar (TSA) or blood agar for bacterial isolation. For culture of oomycetes, shell fragments were dipped in a dilute bleach $(1 \%)$ solution for $30 \mathrm{~s}$ to $1 \mathrm{~min}$ prior to being plated on glucose peptonepenicillin-oxolinic acid agar (GP-POX) and incubated at $22^{\circ} \mathrm{C}$ (Willoughby \& Roberts 1994 , Lilley et al. 1998). Several cultures were established and subcultured on GP-POX. PCR analysis was performed on isolates of the oomycete that grew in cultures.

Genomic DNA was extracted from agar plugs using the QIAamp DNA Stool Kit (Qiagen) following a modification of the manufacturer's protocol (Audemard et al. 2004). In order to confirm that high-quality genomic DNA had been extracted from the agar plugs and could be amplified in PCR, tests were done using the universal small subunit ribosomal RNA (SSU-rRNA) gene primers nSSU-A (5'-CCG AAT TCG TCG ACA ACC TGG TTG ATC CTG CCA GT-3') and nSSU-B (5'-GGA TCC AAG CTT GAT CCT TCT GCA GGT TCC CTA C-3') with an expected amplification product of $\sim 1800$ bp (Medlin et al. 1988). PCR amplification of a fragment of the large subunit rRNA (LSU rRNA) gene was performed using primers P1 and P2 originally designed for amplification of Aphanomyces astaci DNA (Oidtmann et al. 2002). PCR amplification of the 3' end of the SSU-rRNA gene and a portion of the internal transcribed spacer region (ITS) of the rRNA complex (3'SSU/ITS region) was performed using the oomycete primers OMYC-1700F and OMYC2496R (Vandersea et al. 2006). Each PCR reaction con- tained a final concentration of $0.4 \mathrm{mg}$ $\mathrm{ml}^{-1}$ BSA (Idaho Technologies), $10 \mathrm{mM}$ Tris- $\mathrm{HCl}$ at $\mathrm{pH} 8.2,50 \mathrm{mM} \mathrm{KCl}, 0.001 \%$ gelatin, $2 \mathrm{mM} \mathrm{MgCl}_{2}, 0.2 \mathrm{mM}$ of each nucleotide, $1 \mu \mathrm{M}$ of each primer, 0.024 units AmpliTaq Gold DNA Polymerase (Applied Biosystems), and template DNA in a final volume of $25 \mu \mathrm{l}$. The amplification parameters were an initial $4 \mathrm{~min}$ denaturation at $94^{\circ} \mathrm{C}$ followed by 40 cycles of denaturation at $94^{\circ} \mathrm{C}$ for $30 \mathrm{~s}$, annealing at $56^{\circ} \mathrm{C}$ for $30 \mathrm{~s}$, and elongation at $72^{\circ} \mathrm{C}$ for $90 \mathrm{~s}$, with a final elongation of $5 \mathrm{~min}$ at $72^{\circ} \mathrm{C}$ in an MJ Research DNA Engine (Bio-Rad Laboratories). Negative controls consisting of reactants without DNA were run under the same conditions. Positive controls consisting of reactants and other oomycete DNA were not run because the PCR analysis was done to type a known oomycete organism grown in culture, rather than to screen tissue samples. PCR amplification products were separated by electrophoresis using $2.5 \%$ agarose gels. The gels were stained with ethidium bromide for visualization under UV light.

The fragments were cloned into the plasmid PCR4TOPO and transformed into Escherichia coli using the TOPO TA Cloning Kit for Sequencing (Invitrogen) following the manufacturer's protocol. Transformed colonies were screened for inserts of the correct size using cells lysed by a boil-prep as a template for PCR with M13 primers. Selected PCR products were treated with shrimp alkaline phosphatase (SAP) and exonuclease I to remove extra nucleotides and primers. Cleaned PCR products were then sequenced bi-directionally using the Big Dye Terminator Kit v3.1 (Applied Biosystems) with M13 sequencing primers in $5.0 \mu$ reactions following the manufacturer's protocol, except with one-fourth of the concentration of BigDye reagent specified. The cycling parameters for sequencing were an initial $1 \mathrm{~min}$ denaturation at $96^{\circ} \mathrm{C}$ followed by 24 cycles $\left(10 \mathrm{~s}\right.$ at $96^{\circ} \mathrm{C}, 5 \mathrm{~s}$ at $50^{\circ} \mathrm{C}, 4 \mathrm{~min}$ at $\left.60^{\circ} \mathrm{C}\right)$. Capillary electrophoresis was done on a 3130xl Genetic Analyzer (Applied Biosystems). Sequences were verified and contigs assembled using Sequencher (version 3.1, Gene Codes) and both the LSU rRNA gene and 3'SSU/ITS region sequences were subjected to a nucleotide BLAST search of the NCBI database (http:// blast.ncbi.nlm.nih.gov/Blast.cgi). The sequences have been deposited in GenBank under accession numbers GQ919078 and GQ919079 for the LSU rRNA gene and 3'SSU/ITS region fragments, respectively. Phylogenetic analysis was done using published methods (Johnson et al. 2006). 


\section{RESULTS}

\section{Disease occurrence, distribution, and transmission}

Although both Orconectes virilis and $O$. propinquus have historically occurred in Big Muskellunge Lake, the former have been at very low densities recently, and only $O$. propinquus entered traps during the present study. In 2006, 2931 O. propinquus were trapped across the 4 sampling events. Of these, 279 (9.5\%) had externally visible ulcers. The sex ratio was 6.73 males captured for every 1 female. The sex ratio for infected crayfish was not determined. On average, infected crayfish (total length $=5.66 \mathrm{~cm}, \mathrm{SD}=0.85$ ) were significantly smaller $(p<0.001)$ than uninfected crayfish (total length $=6.28 \mathrm{~cm}, \mathrm{SD}=0.73$ ). Crayfish also tended to be larger at the 2 deepest transect depths.

The prevalence of ulcers among sampled crayfish varied by site and by sample date, ranging from a minimum of $3.3 \%$ to a maximum of $21.5 \%$ (site: $\chi^{2}=44.71$, $\mathrm{df}=3, \mathrm{p}<0.0001$; date: $\chi^{2}=44.71, \mathrm{df}=3, \mathrm{p}<0.0001$ ). The overall occurrence of ulcers at each site was as follows: Site 1: $15.4 \%(\mathrm{n}=845)$; Site 2: $11.6 \%(\mathrm{n}=606)$; Site 3: $8.6 \%(\mathrm{n}=773)$; and Site $4: 9.5 \%(\mathrm{n}=922)$. The prevalence of ulcerated crayfish exhibited an apparent seasonal pattern, typically with low prevalence (1.6 to $3.9 \%$ ) in early June and rising to a subsequent peak in July and August (11.9 to $21.5 \%$ ) (Fig. 3A).

The prevalence of ulcers also exhibited a marked variation among sample depths $\left(\chi^{2}=29.82, \mathrm{df}=6, \mathrm{p}<\right.$ 0.0001). After aggregating the data among sites, we noted that the prevalence of ulcers exhibited a bimodal pattern with disease peaks at both shallow (0.5 to $1.5 \mathrm{~m}$ ) and deep (4.5 to $6.5 \mathrm{~m}$ ) sites (Fig. 3B).

In the aquarium trials, we detected no transmission of the ulcerous condition, either intraspecifically or interspecifically. Ulcerative disease did not spread from infected crayfish with lesions to either healthy Orconectes propinquus or to healthy $O$. rusticus within the 4 wk observation period. Three uninfected and 4 infected crayfish died during the co-housing experiment and these individuals were not replaced. Exposed animals were not cultured for Saprolegnia australis infection.

\section{Ulcerative lesions}

Of the crayfish inspected visually, there were 61 lesions on the walking legs and 37 lesions on the claws (Table 2). Histologically, the borders of ulcers were necrotic and discolored brownish-black by melanin deposition. Lesions were highly melanized, a characteristic that is consistent with the host reaction to infection with microbial agents. Oomycete hyphae were present in the ulcers along with infiltrates of hemo-
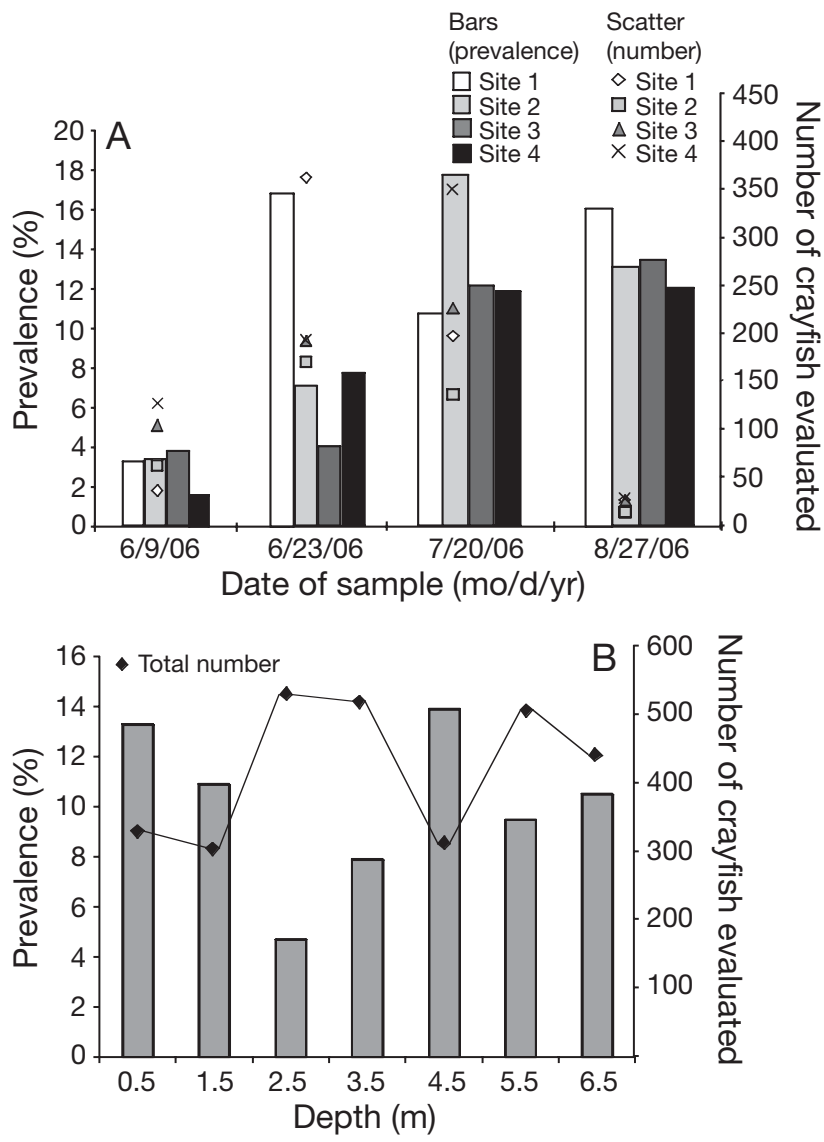

Fig. 3. Orconectes propinquus. Numbers of infected and uninfected crayfish and prevalence of infected crayfish (A) at each sampling site for each of the 4 dates $(\mathrm{mo} / \mathrm{d} / \mathrm{yr})$ and (B) at different depths

cytes that extended into the adjacent tissues (Fig. 4), suggesting an infectious etiology for the pathology, likely due to Saprolegnia australis. Correspondingly, cultures of samples from lesions containing hyphae were positive for $S$. australis, establishing it as a likely causative agent of the ulcerations. In some crayfish, Psorospermium haekelii and a species of Thelohania were present in histologic sections, but they were not associated with the oomycete infections. Bacterial cultures of the ulcers grew Aeromonas sobria, a common secondary pathogen in aquatic organisms.

Table 2. Orconectes propinquus. Distribution of 155 ulcers

\begin{tabular}{|lc|}
\hline Anatomical area & Number of lesions (\%) \\
\hline Carapace & $22(14.1)$ \\
Claws & $37(23.9)$ \\
Walking legs & $61(39.3)$ \\
Abdomen & $15(9.68)$ \\
Tail, uropod, and telson & $20(12.9)$ \\
\hline
\end{tabular}




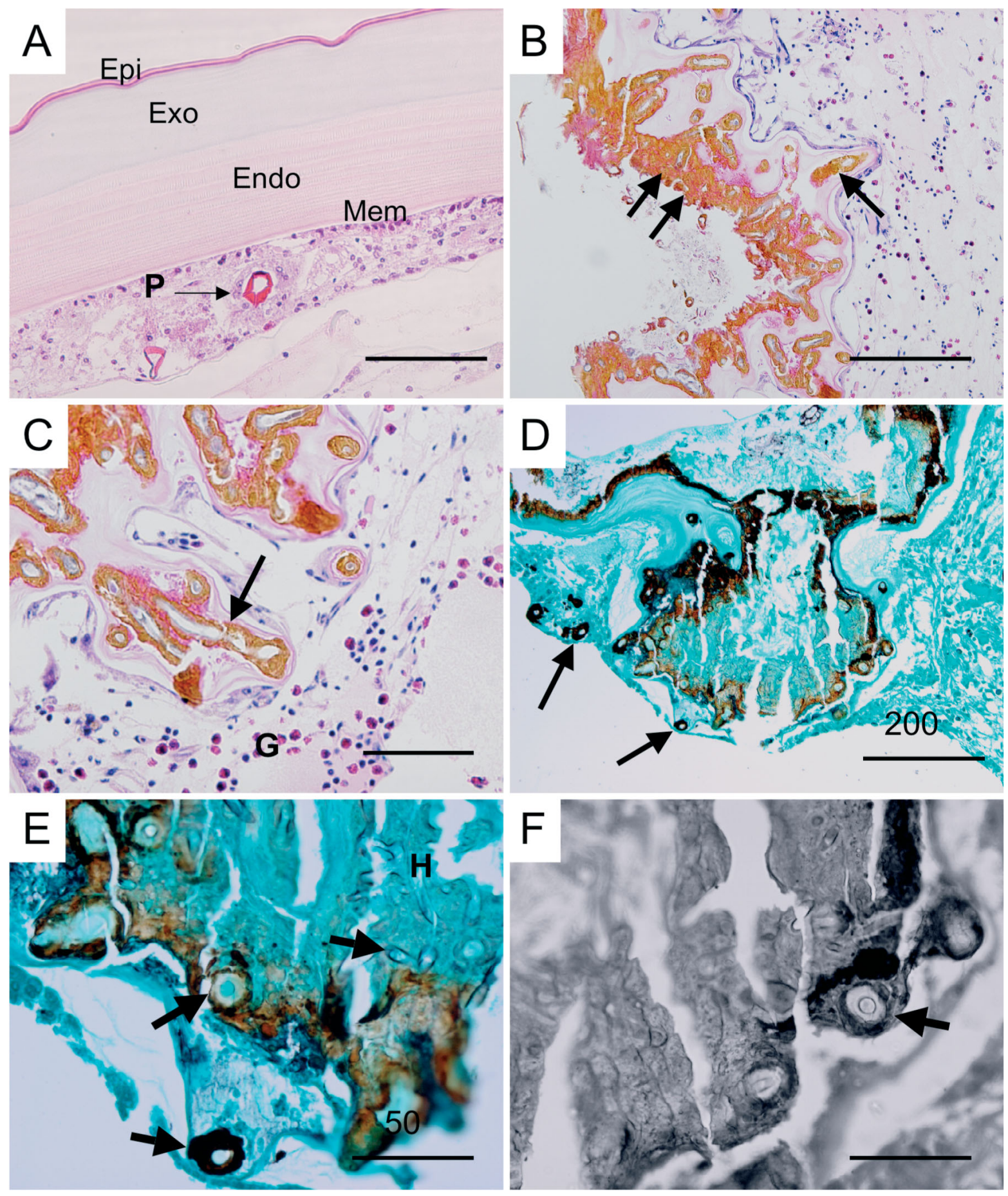

Fig. 4. Orconectes propinquus. (A) Healthy carapace showing the typical organization of the cuticle into epicuticle (Epi), exocuticle (Exo), endocuticle (Endo), and membranous layer (Mem). P: Psorospermium haekelii sporont. H\&E. Scale bar $=200 \mu m$. (B) Carapace that is severely infected, putatively by Saprolegnia australis, showing lytic disruption of the cuticle, melanotic response to infection (arrows), and encapsulated hyphae. H\&E. Scale bar $=200 \mu \mathrm{m}$. (C) Detail from the same animal as in (B) showing the melanotic response that has developed along a hypha (arrow) that has grown into the dermis. Note the infiltrating granulocytes (G). H\&E. Scale bar $=100 \mu \mathrm{m}$. (D) An ulcerative lesion that is heavily melanized (black areas) with hyphae (arrows) penetrating through the cuticle. GMS stain. Scale bar $=200 \mu \mathrm{m}$. (E) Detail of ulceration in (D) demonstrating hyphae (H) (arrows) in the lesion and penetrating into the epidermis. GMS stain. Scale bar $=50 \mu \mathrm{m}$. (F) Detail of ulceration in (D) showing hyphae (arrow) in the leading edge of the lesion. The hyphae elicit an intense melanitic response. GMS stain. Scale bar $=50 \mu \mathrm{m}$. 


\section{Culturing and molecular identification of Saprolegnia australis}

A 954 bp fragment was amplified from high-quality DNA extracted from isolates that grew on the GP-POX agar using primers targeting the LSU rRNA gene, and a 756 bp fragment was amplified using primers targeting a fragment containing a small portion of the SSU rRNA gene and the ITS region of oomycetes (Fig. 5). The 5 sequences resulting in the highest-scoring segment pairs from the BLAST search using the LSU rRNA gene fragment amplified from the isolate DNA were from Achlya recemosa, Achlya colorata, Leptolegnia sp., and Aphanomyces astaci, and the sequence similarities ranged from 95 to $98 \%$ across the entire fragment. The 5 ITS region sequences resulting in the highest-scoring segment pairs from the BLAST search using the ITS region sequence were from Saprolegnia australis, S. ferax, and a Saprolegnia sp. The ITS region sequence from the top-scoring $S$. australis (GenBank accession no. AB219385) showed $100 \%$ identity to the portion of the PCR fragment containing only the ITS region sequence. The $3^{\prime}$ end of the SSU rRNA gene portion ( $90 \mathrm{bp}$ ) of this PCR fragment showed 97 to $98 \%$ identity to SSU rRNA gene sequences of Saprolegnia spp. (GenBank accession nos. FJ94908 and AJ238655). Note that at the time that

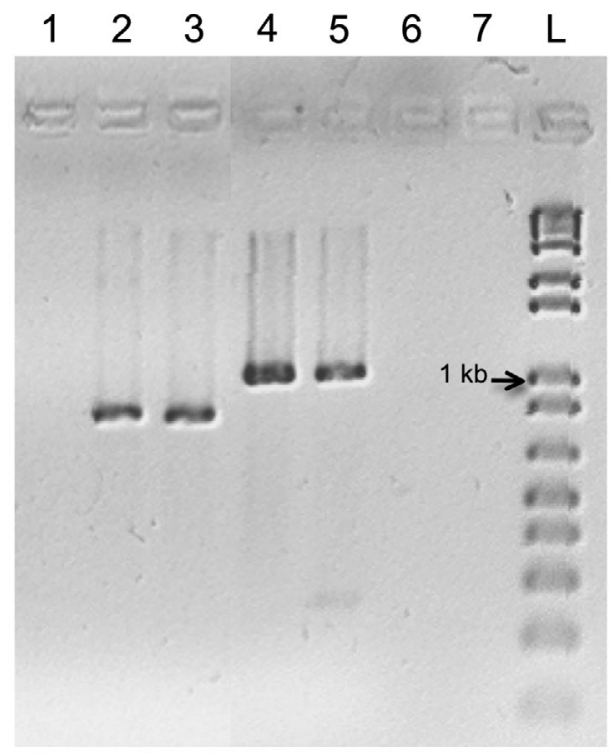

Fig. 5. Negative of ethidium bromide-stained agarose gel showing PCR amplification products obtained from the DNA of the oomycete isolated from the carapace of Orconectes propinquus. Lanes 2 and 3: PCR with the 3'SSU/ITS region primers OMYC-1700F and OMYC-2496R (Vandersea et al. 2006). Lanes 4 and 5: LSU rRNA gene products from PCR with primers P1 and P2 (Oidtmann et al. 2002). Lanes 1 and 6: negative PCR controls. Lane 7: blank. Lane L: $1 \mathrm{~kb}$ Plus DNA ladder (Invitrogen) these BLAST searches were conducted there were no sequences for LSU rRNA gene fragments longer than $\sim 40 \mathrm{bp}$ of the 5' end of the gene for Saprolegnia spp. in the database. Phylogenetic analysis showed that the amplified sequences were closest to known sequences from $S$. australis (Fig. 6).

\section{DISCUSSION}

Molecular identification of the organism that grew in culture was done based on DNA sequences of the 3'SSU/ITS fragment and that of the LSU rRNA gene. BLAST analysis of the 3'SSU/ITS region suggested that the organism was Saprolegnia australis as there was $100 \%$ sequence identity in the ITS portion of the fragment to ITS region sequences previously deposited in GenBank for this species. The 3' SSU rRNA gene portion of the fragment suggested that this was a Saprolegnia species, although there were no SSU rRNA gene sequences in the database for $S$. australis. In addition, no LSU rRNA gene sequences of any substantial length (i.e. $>50$ bp) were available in the database for any Saprolegnia species and the highest-scoring sequences were therefore sequences from other oomycetes including Achlya spp., Leptolegnia spp., and Aphanomyces spp. The SSU and LSU rRNA genes are typically rather highly conserved sequences, while the ITS region is more variable. Therefore, the matching ITS region sequences and overall results of the molecular analyses strongly suggest that the pathogen is $S$. australis (Fig. 6).

This is the first reported occurrence linking Saprolegnia australis infection with ulcerative disease in crayfish from the USA. Diseased crayfish had ulcerated lesions in the cuticle that were largely confined to the carapace and extremities. The gross and histologic appearance of lesions and their extent was consistent with infection by an oomycete (Figs. $2 \& 4$ ). Moreover, $S$. australis was cultured from the lesions. Host reactions to hyphal growths in the cuticle, consisting of hemocytic infiltrates, granulocytic reactions, and melanin deposition, were also characteristic of this type of infection (Edgerton et al. 2002).

Although Saprolegnia parasitica has been reported previously to cause ulcerative disease in crayfish (Edgerton et al. 2002), these reports are rare in naturally occurring host populations relative to studies of the related oomycete, Aphanomyces astaci. A. astaci, the causative organism of crayfish plague ('krebspest'), is one of the most economically important pathogens of Old World crayfish and one that is very commonly reported in the literature (Johnson 1983). The organism is enzootic in North American crayfish, in which it is carried as an asymptomatic infection and has not 


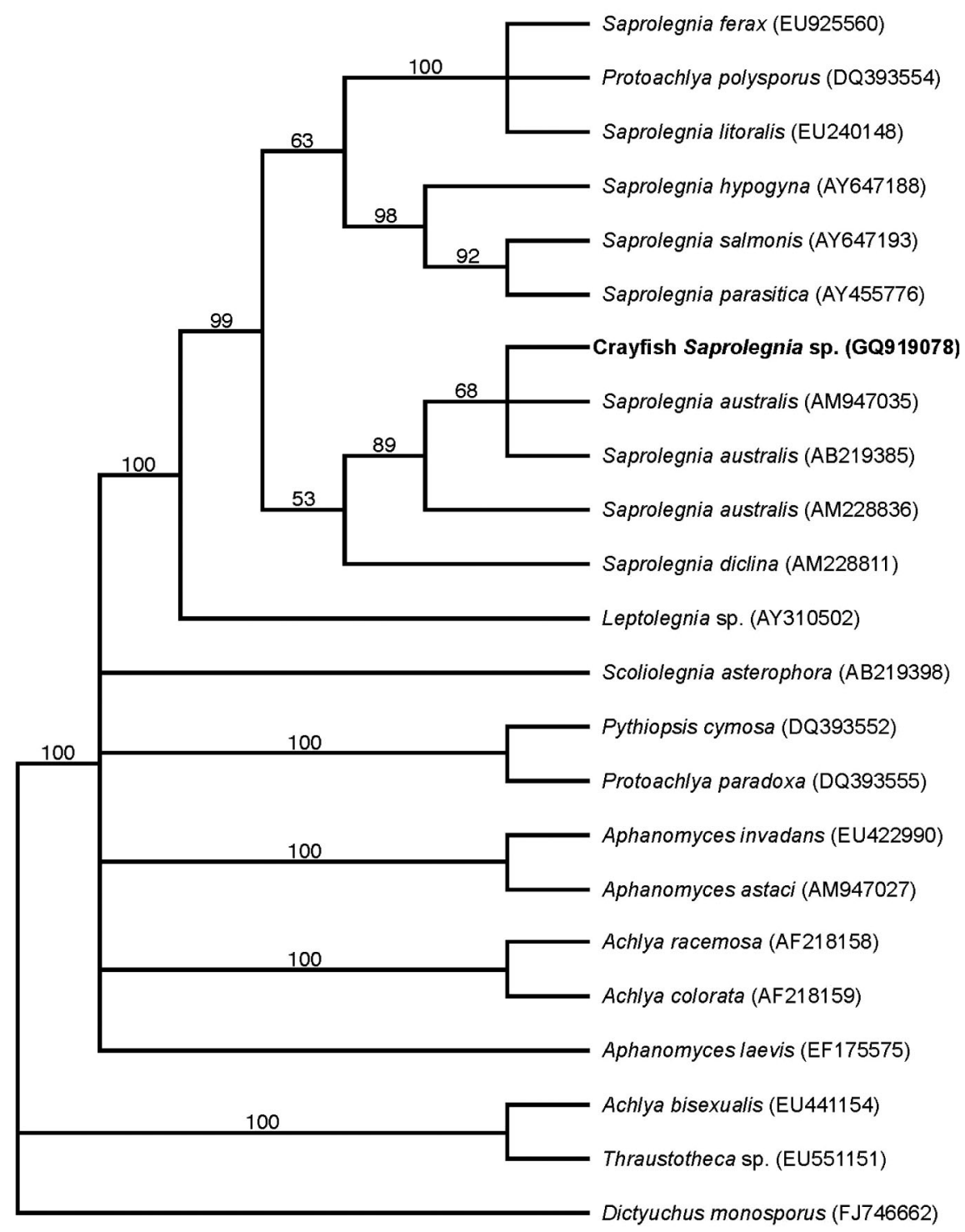

Fig. 6. Parsimony bootstrap tree resulting from analysis of the ITS sequence of the Saprolegnia sp. isolated from Orconectes propinquus (bold) with sequences of other members of the Saprolegniaceae. Boostrap support values are given for clades with $>50 \%$ support. Note strong support (89\%) for placement of the crayfish Saprolegnia sp. in the S. australis clade. Analysis was conducted with 1000 bootstrap replicates of 100 random additions

been reported to cause disease except under specific environmental conditions. Following the introduction of North American crayfish to Europe, however, $A$. astaci is now widely disseminated in European crayfish populations and has decimated native crayfish species in river drainages across Scandinavia, Poland, and France (Edgerton et al. 2004).

In Big Muskellunge Lake, the prevalence of infected crayfish varied by site location, the date of collection, and the depth at which the sample was taken. The observed spatial and temporal distribution of crayfish and the prevalence of infected animals may be due to the type of crayfish caught or by the type of traps used in this study. Minnow traps tend to bias toward aggressive male crayfish (Rabeni et al. 1997), consistent with the patterns in our own data showing a strong male bias. In Orconectes propinquus, aggressive males usually comprise the largest size class (Dorn et al. 2005). The observed seasonal increase in ulcer prevalence could be related to increases in water temperature, increases in overall crayfish density, or a combination of both factors (Fig. 3A). SCUBA divers surveying Big Muskellunge Lake noted very high densities of crayfish on the bottom of the lake in 2006, of which approximately 5 to $10 \%$ were dead (S. Devlin pers. comm.). The association between smaller numbers of total cray- 
fish and higher prevalence of infected individuals could be due to the effect of the infection on the population, as an artifact of increased mortality. Alternatively, infected crayfish may have moved to other depths. Additional studies would be necessary to distinguish between the 2 possibilities.

Co-habitation of infected Orconectes propinquus with uninfected $O$. propinquus or O. rusticus over a $4 \mathrm{wk}$ period did not lead to detectable transmission of the ulcerative disease associated with Saprolegnia australis. The conditions under which transmission of Saprolegnia spp. occurs under natural conditions may be difficult to replicate in the laboratory. We did not sample zoospore abundance or viability during the exposure experiment. It is distinctly possible that infections are transmitted during the molting of the host. This is a relatively common occurrence in diseases such as this, albeit not well documented except for rhizocephalan infections in crabs and some protozoal infections in crabs and lobsters (Tindle et al. 2004, Shields et al. 2007). Because crayfish were collected in nature, however, we acknowledge the possibility that wild-caught individuals may also vary in infection or disease susceptibility.

Another possibility is that infection occurs in association with a secondary stress event, such as damage to the cuticle. Wounds serve as a portal of entry for several pathogens in crustaceans, e.g. gaffkemia in lobsters, and ciliates in crabs (Morado \& Small 1995, Tlusty et al. 2007). Most of the crayfish sampled in the present study were males, and most ulcerative lesions were on the extremities, consistent with possible injury sites for male crayfish in aggressive encounters (Table 2). Zoospores of Saprolegnia spp. and Aphanomyces astaci will swim toward the exudates from open wounds in crayfish (Edgerton et al. 2002). In a laboratory experiment using 3 different European species, crayfish were 3 times more likely to become infected and die if the epicuticle was experimentally abraded prior to exposure to zoospores (Edgerton et al. 2002). Wounded fish are also more likely to be colonized by $S$. parasitica or a related aphanomycete, A. invadans, than fish with an intact integument (Carballo et al. 1995, Kiryu et al. 2002, 2003). Wounding due to aggression may also increase with population density of crayfish. This idea is supported by the increase in the number of crayfish in Big Muskellunge between 1981 and 2008 (J. A. Rusak unpubl. data), but the number of wounds on monitored animals was not recorded. It is not possible to say with certainty whether this oomycete is an exotic or emerging pathogen, and why it has been identified at this time, but the increasing density of crayfish could lead to increased aggression and wounding, giving $S$. australis more opportunities to infect the open wounds.
In the present study, we document an epizootic of ulcerative disease in Orconectes propinquus from a lake in northern Wisconsin with a > 20 yr sampling history. The health of the crayfish in this lake and in several others will continue to be monitored as part of the ongoing LTER project. The identification of ulcerated crayfish in 2005 and 2006 in a lake where this disease had not been observed before highlights the utility of long-term monitoring efforts in the context of wildlife disease surveillance. Prospective studies of this nature should also assist in identifying the ecological risk factors associated with saprolegniasis in crayfish. Further study is needed to (1) evaluate the consequences of ulcerative pathology for affected crayfish populations, (2) verify the causative link between Saprolegnia australis and observed pathology, and (3) understand the environmental factors that drive variation in disease prevalence and severity.

Acknowledgments. We thank K. Wheeler at VIMS for expertise in culturing the agent and histology and G. Scott for expert technical assistance and proofreading.

\section{LITERATURE CITED}

Audemard C, Reece KS, Burreson EM (2004) Real-time PCR for the detection and quantification of the protistan parasite Perkinsis marinus in environmental waters. Appl Environ Microbiol 70:6611-6618

Baldauf SL (2003) The deep roots of eukaryotes. Science 300: 1703-1706

> Blaustein AR, Wake DB (1995) The puzzle of declining amphibian populations. Sci Am 272:52-57

Carballo M, Munoz M, Cuellar M, Tarazona JV (1995) Effects of waterborne copper, cyanide, ammonia and nitrate on stress parameters and changes in susceptibility to saprolegniosis in rainbow trout (Oncorhynchus mykiss). Appl Environ Microbiol 61:2108-2112

> Dorn NJ, Urgalles R, Trexler JC (2005) Evaluating active and passive sampling methods to quantify crayfish density in a freshwater wetland. J N Am Benthol Soc 24:346-356

$>$ Edgerton BF, Evans LH, Stephens FJ, Overstreet RM (2002) Synopsis of freshwater crayfish diseases and commensal organisms. Aquaculture 206:57-135

Edgerton BF, Henttonen P, Jussila J, Mannonen A and others (2004) Understanding the causes of disease in European freshwater crayfish. Conserv Biol 18:1466-1474

Hirsch PE, Nechwatal J, Fischer P (2008) A previously undescribed set of Saprolegnia spp. in the invasive spiny-cheek crayfish (Orconectes limosus, Rafinesque). Fundam Appl Limnol (Arch Hydrobiol) 172:161-165

Johnson PT (1983) Diseases caused by viruses, rickettsiae, bacteria and fungi. In: Provenzano AJ (ed) The biology of Crustacea, Vol 6. Pathobiology. Academic Press, New York, NY, p 1-78

Johnson PTJ, Longcore JE, Stanton DE, Carnegie RB, Shields JD, Preu ER (2006) Chytrid infections of Daphnia pulicaria: development, ecology, pathology and phylogeny of Polycaryum leave. Freshw Biol 51:634-648

Kiesecker JM, Blaustein AR (1995) Synergism between UV-B radiation and a pathogen magnifies amphibian embryo 
mortality in nature. Proc Natl Acad Sci USA 92: 11049-11052

Kiesecker JM, Blaustein AR, Miller CL (2001) Transfer of a pathogen from fish to amphibians. Conserv Biol 15: 1064-1070

Kiryu Y, Shields JD, Vogelbein WK, Zwerner DE, Kator H, Blazer VS (2002) Induction of skin ulcers in Atlantic menhaden by injection and water-borne exposure to the zoospores of Aphanomyces invadans. J Aquat Anim Health 14:11-24

Kiryu Y, Shields JD, Vogelbein WK, Kator H, Blazer VS (2003) Infectivity and pathogenicity of the oomycete Aphanomyces invadans in Atlantic menhaden Brevoortia tyrannus. Dis Aquat Org 54:135-146

Lilley JH, Callinan RB, Chinabut S, Kanchanakhan S, MacRae IH, Phillips MJ (1998) Epizootic ulcerative syndrome (EUS) technical handbook. The Aquatic Animal Health Research Institute, Bangkok

Luna LG (ed) (1968) Manual of histologic staining methods of the Armed Forces Institutes of Pathology, 3rd edn. McGraw-Hill Book Co., New York, NY

Medlin L, Elwood HJ, Stickel S, Sogin ML (1988) The characterization of enzymatically amplified eukaryotic 16S-like rRNA-coding regions. Gene 71:491-499

Morado JF, Small EB (1995) Ciliate parasites and related diseases of Crustacea: a review. Rev Fish Sci 3:275-354

Oidtmann B, Bausewein S, Hölzle L, Hoffmann R, Wittenbrink M (2002) Identification of the crayfish plague fungus Aphanomyces astaci by polymerase chain reaction and

Editorial responsibility: Ken Hasson, College Station, Texas, USA restriction analysis. Vet Microbiol 85:183-194

Rabeni CF, Collier KJ, Hicks BJ (1997) Evaluating techniques for sampling stream crayfish. NZ J Mar Freshw Res 31: 693-700

Shields JD, Taylor DM, O'Keefe PG, Colbourne E, Hynick E (2007) Epidemiological determinants in outbreaks of bitter crab disease (Hematodinium sp.) in snow crabs Chionoecetes opilio from Conception Bay, Newfoundland, Canada. Dis Aquat Org 77:61-72

Tindle S, Boone E, O'Brien J, Boettcher A (2004) Effects of salinity on larval stages of the rhizocephalan barnacle Loxothylacus texanus: survival and metamorphosis in response to the host Callinectes sapidus. J Exp Mar Biol Ecol 302:165-176

Tlusty MF, Smolowitz RM, Halvorson HO, DeVito SE (2007) Host susceptibility hypothesis for shell disease in American lobsters. J Aquat Anim Health 19:215-225

> Torto-Alalibo T, Tian M, Gajendran K, Waugh ME, van West P, Kamoun S (2005) Expressed sequence tags from the oomycete fish pathogen Saprolegnia parasitica reveal putative virulence factors. BMC Microbiol 5:46-59

Vandersea MW, Litaker W, Yonnish B, Sosa E and others (2006) Molecular assays for detecting Aphanomyces invadens in ulcerative mycotic fish lesions. Appl Environ Microbiol 72:1551-1557

Willoughby LG, Roberts RJ (1994) Improved methodology for isolation of the aphanomyces fungal pathogen of epizootic ulcerative syndrome (EUS) in Asian fish. J Fish Dis 17: $541-543$

Submitted: November 4, 2009; Accepted: May 5, 2010 Proofs received from author(s): July 14, 2010 